Original article. January-April 2018; 8(1):91-101. Received: 12/06/2017 Accepted: 10/09/2017.

http://dx.doi.org/10.21929/abavet2018.81.9

\title{
Cacería de venados Odocoileus virginianus, Mazama americana (Artiodactyla: Cervidae) en tres comunidades de Yucatán
}

\author{
Deer hunting Odocoileus virginianus, Mazama americana (Artiodactyla: Cervidae) in \\ three communities of Yucatan
}

\author{
Montes-Pérez Rubén* mperez@correo.uady.mx, Ek-May Pedro \\ biol_pedroek@outlook.com, Aguilar-CorderoWilian acordero@correo.uady.mx, Magaña- \\ Monforte Juan jmagana@correo.uady.mx, Montes-Cruz Fausto javiermontes86@gmail.com
}

Campus de Ciencias Biológicas y Agropecuarias. Universidad Autónoma de Yucatán. México. *Author responsible and correspondence: Montes-Pérez Rubén. Campus de Ciencias Biológicas y Agropecuarias. Universidad Autónoma de Yucatán. Carretera Mérida-Xmatkuil km 15.5. CP. 97315 Mérida, Yucatán, México.

\section{RESUMEN}

El objetivo del trabajo fue caracterizar la cacería de venados $O$. virginianus y $M$. americana en tres comunidades rurales del municipio de Tzucacab, Yucatán, México. Se utilizó la técnica de muestreo de bola de nieve para identificar a los campesinos/cazadores, y con ellos se aplicó la técnica de encuesta, entrevista abierta y a profundidad, observación participativa y el registro de datos biométricos de los ejemplares cazados. Los resultados mostraron que la principal técnica de cacería es la batida. La cantidad de cazadores para la batida fluctúa entre 3 y 14, esta actividad se efectúa a lo largo del año. La cantidad total de animales extraídos en una semana de registro para cada uno de los cuatro meses fue de 12 ejemplares, con una biomasa total de $512 \mathrm{~kg}$, siendo $455 \mathrm{~kg}$ de carne de $O$. virginianus y $57 \mathrm{~kg}$ de $M$. americana. Se cazan hembras y machos de diferentes pesos, sin embargo, se informa de la extracción de venados que no son aprovechados, denominados heridos-mal tirados, porque sufren el impacto del disparo, pero no son derribados y escapan a la cosecha. El impacto que tiene la cacería frecuente de venados sobre la viabilidad de sus poblaciones se desconoce y es necesario investigarla.

Palabras clave: cacería, Mazama, Odocoileus, venado cola blanca, venado temazate.

\begin{abstract}
The objective of this paper was to characterize the hunting of deer $O$. virginianus and $M$. americana in three rural communities in the municipality of Tzucacab, Yucatán, Mexico. The snowball technique was used to identify the peasants/hunters, and with them applied the techniques of survey, open and depth interviewing, participatory observation and the recording of biometric data of specimens hunted. The results showed that the main technique of hunting is the "beating". The number of hunters for the "beating" fluctuates between 3 and 14 this activity is carried out throughout the year. The total number of animals in a week of record for each of the four months was 12 individuals, with a total biomass of $512 \mathrm{~kg}$, of which $455 \mathrm{~kg}$ were of meat of $O$. virginianus and $57 \mathrm{~kg}$ of $M$. americana. Males and females of different weights are hunted, however, reported the removal of deer that are not exploited, called "injured- bad fired", because they suffer from the impact of the shot but they are not broken down and escape to harvest. The impact of frequent hunting of deer on the viability of their populations is unknown and it is necessary to investigate.
\end{abstract}

Key words: hunting, Mazama, Odocoileus, white-tailed deer, brocket deer. 


\section{INTRODUCTION}

Although the origin of the direct exploitation of the fauna and flora appears with the same history of the human societies, at the moment intense activity of the hunt has been reported. Naranjo et al. (2010) mention that in the Lacandona jungle, 190 hunters from five rural communities extracted 782 animals, mainly birds, mammals and reptiles; the amounts reached values of 8.2 tons of meat, equivalent to $43.2 \mathrm{~kg} / \mathrm{hunter}$, per year.

In the state of Yucatan, hunting is a practice rooted in rural communities, where fun, traditions, and the need for meat for food and lack of employment are some of the factors that lead to wildlife hunting (Landewee, 2009; Montiel and Arias, 2008).

According to the report of Segovia (2001), in the municipality of Tzucacab, Yucatan; the deer are the most hunted, especially white-tailed (Odocoileus virginianus) and brocket one (Mazama americana), information that is similar to that reported by Narvaez (2017), as for white-tailed deer in Yucatan.

A critical analysis of this practice in Yucatan (Robles de Benito, 2010) reveals that there are other economic and political factors that lead to the exploitation of wildlife. The author mentions: "The reality is that deer are still being hunted without control and without sanction, in a sort of 'clandestinity' that is more a kind of voluntary blindness on the part of the authorities of the three levels of government. This panorama, it is not surprising that opportunistic commercial hunters and, of course, better equipped and armed than the peasants ... go to communal or national lands and contribute to reduce the numbers of local populations of deer.

From 1997 the Federal government proposed to direct the Mexican policy in the matter of wildlife conservation towards the operation of the binomial conservation and exploitation; in 2000 the General Law of Wildlife was published in the Official Gazette of the Federation, this document indicates the legal measures to control and sanction the conduct of citizens who have activities on the use of Mexican wild flora and fauna, providing regulatory mechanisms on the use, extractive and non-extractive of parts and derivatives of wildlife; being the hunting one of the forms of extractive exploitation of wild fauna.

As it can be observed, the activity of the hunt has an impact on some species of fauna mainly of deer, at least in Yucatan state; (Odocoileus virginianus, Mazama americana), through subsistence hunting in three rural communities in the municipality of Tzucacab in the state of Yucatán, Mexic for this the objective of the present study was to characterize 
the biological importance, uses and exploitation of deer (Odocoileus virginianus, Mazama americana).

\section{MATERIAL AND METHODS}

The study area is located in the municipality of Tzucabab in the southern state of Yucatan, Mexico. In the region the climate is subhumid warm, classifying as $A^{\prime}(w o)\left(i^{\prime}\right) g$, rains occur in summer and winter (Orellana and Espadas, 2010).

The present investigation was carried out in the communities: Blanca Flor, Xcobiakal and El Corral; first they visited the three localities, to contact the authorities of Tzucacab municipal head, ejido commissaries and later to key informants, peasants / hunters; to which a survey and in-depth interviews were applied, which allowed to obtain data of their activities, type of hunting, uses and exploitation of the deer hunted; participatory observation and recording of direct biological data of each hunting event were also used; weights, height, body development and number of deer hunted were recorded in the three participating police stations. The data were analyzed and processed through an Excel database; this stage was done during four months: October and November of 2009, January and March of 2010.

For the selection of the participants, the non-probabilistic sampling method, called Snowball was used in situations where it is difficult to locate the members of a specific group (Martínez-Salgado, 2012); in this case the peasants / hunters, especially because they retain discretion to manifest their hunting practices. In this work the denomination peasant/hunter is used, because the participants in the events of hunting are dedicated to two main activities, the agriculture and hunting.

\section{RESULTS AND DISCUSSION}

Hunting techniques: among the various hunting techniques reported in the surveys $(n=47)$, the most frequent used by the peasants/hunters of the three communities was "walking in the bush" (90\%), followed by "beating" (40\%), "spy" (20\%) and "lampareo" (6.7\%). However, participatory observation revealed that $72.7 \%(16 / 22)$ opted for the "beating" and 9.09\% (2/22) for "walking on bush"; because when going out in "beating" and with the help of dogs is more likely to find and hunt the prey.

Figure 1 left, shows a group of peasants / hunters and their dogs; Figure 1 right, shows the meat in portions to be distributed between them. Table 1 shows detailed information on the hunting technique at each study site through participatory observation. The frequency of hunting events in the four months of study was higher in the community of El 
Corral (12 hunting trips), followed by Xcobiakal (6 exits) and Blanca Flor (4 exits), completing 22 exits.

The favorite hunting site was the forest in different states of succession, where the largest number of prey was collected (white-tailed deer), registering $83.3 \%$ of hunted animals; while corn field (milpa) reached only $16.7 \%$, which is close to what was found in Tzucacab by Segovia (2001), who reported that in secondary vegetation presented $21 \%$ of records and in the corn field $18.4 \%$. The favorite hunting sites denotes the knowledge of the peasants/hunters by the food preferences and areas of refuge of the animals to hunt; they know that where the forest is less disturbed, wildlife can find shelter, as Coba (2011) indicates, which reports the preferential use of deer by the forest on old or corn field.
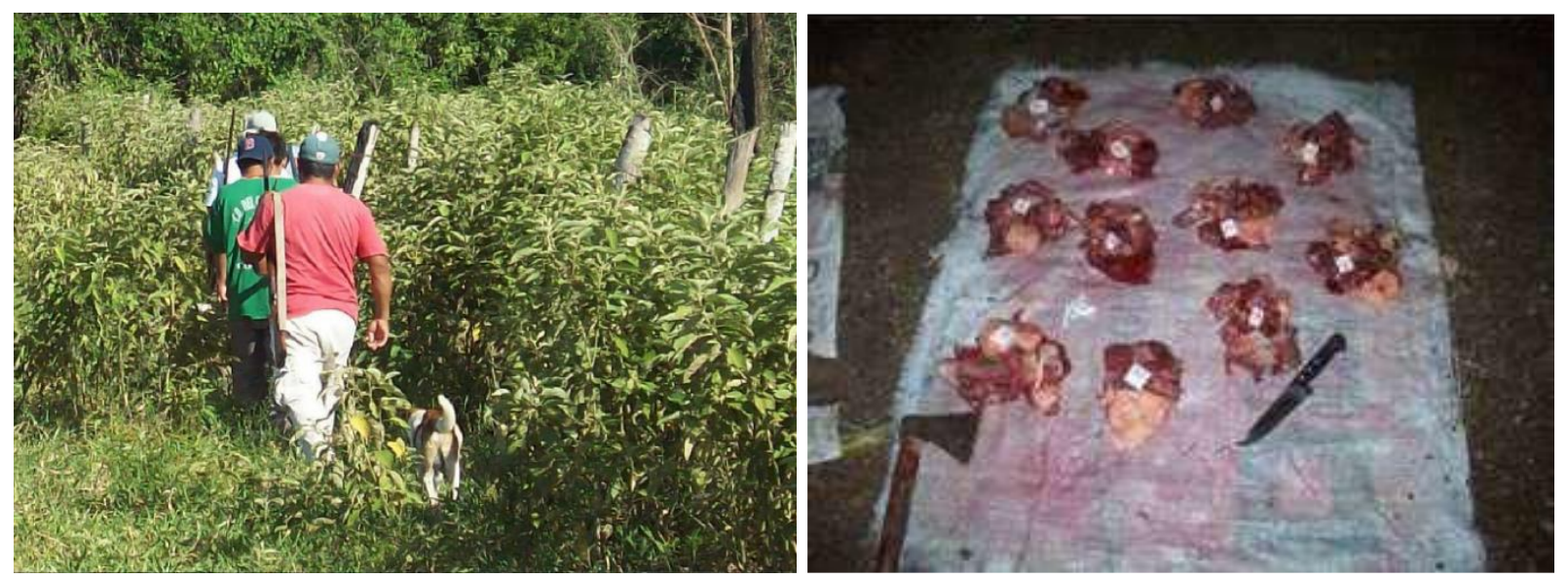

Figure 1. In the left photo, a group of hunters are directed to apply the technique of "beating". The right photo shows lots of venison distributed among the hunters.

Most of prey obtained were by means of the technique of "beating" using caliber 16 shotgun and 22 caliber rifle, with which they use of 1 to 4 shots, being the most frequent only 1 (59\%); which means that the peasants/hunters have little chance to repeat the shot on the prey. The number of dogs is 3 to 8 in the "beating", which means that the function of the dogs is very important to locate the traces of deer, and in this way have a greater probability of hunting it, especially since the dogs they use have been trained for that purpose.

The number of peasants/hunters involved in the "beating" varies from a minimum of 3 to 14; these data coincide with Landewee (2009), which reports that "beating" groups are 5 to 20 people. There is a marked contrast in the number of members in the "beating", according to the comments of the same peasants / hunters, some of the conditions by which there is a difference in the number of participants is that the greater number of peasants / hunters corresponds a smaller proportion of meat for each, due to the 
distribution among the participants, or the migration of peasants/hunters to the big cities to work as laborers in the construction, therefore small groups would be formed.

The highest frequency of hunting is at daytime, approximately between 2:00 and 3:00 pm, the hunting schedule is made after the normal work of the farmer/hunter and it is linked to the availability of time of the owners of the dogs; therefore there is no regularity in the frequency and number of participants in the "beating"; these results coincide with that reported by Landewee (2009), which mentions that hunting is frequently at daytime in rural communities of Yucatan.

Table 1. Hunting technique, number of participants, shots and type of weapon used during hunting activity in the three communities studied.

\begin{tabular}{|c|c|c|c|c|c|}
\hline Locality & $\begin{array}{l}\text { Hunting } \\
\text { techniques }\end{array}$ & $\begin{array}{c}\text { Amount } \\
\text { of } \\
\text { hunters }\end{array}$ & $\begin{array}{c}\text { Calibers of } \\
\text { firearms }\end{array}$ & $\begin{array}{l}\text { Number } \\
\text { of shots }\end{array}$ & $\begin{array}{c}\text { Number of } \\
\text { dogs }\end{array}$ \\
\hline Corral & Beating & 3 & 16 and 22 & 2 & 5 \\
\hline Xcobiacal & Spy & 1 & 22 & 1 & 5 \\
\hline Xcobiacal & Beating & 14 & 22 & 2 & 6 \\
\hline Corral & Beating & 5 & 16 and 20 & 2 & 5 \\
\hline Corral & Beating & 3 & 16 and 22 & 2 & 5 \\
\hline Corral & Beating & 3 & 16 and 20 & 1 & 8 \\
\hline Corral & $\begin{array}{c}\text { Walk in the } \\
\text { bush }\end{array}$ & 1 & 16 & 1 & 5 \\
\hline Corral & $\begin{array}{c}\text { Walk in the } \\
\text { bush }\end{array}$ & 1 & 16 & 1 & 0 \\
\hline Corral & Beating & 3 & 16 and 22 & 1 & 5 \\
\hline Xcobiacal & Beating & 7 & 16 & 1 & 8 \\
\hline Xcobiacal & Lamparear & 2 & 16 and 20 & 1 & 0 \\
\hline Blanca Flor & Beating & 6 & 16 and 20 & 2 & 4 \\
\hline Blanca Flor & Beating & 6 & 16 and 20 & 1 & 4 \\
\hline Blanca Flor & Beating & 6 & 16 and 20 & 1 & 3 \\
\hline Blanca flor & Beating & 3 & 20 & 1 & 3 \\
\hline Corral & Beating & 5 & 16 and 20 & 3 & 8 \\
\hline Corral & Beating & 5 & 16 and 20 & 3 & 5 \\
\hline Corral & Beating & 5 & 16 and 20 & 4 & 4 \\
\hline Xcobiacal & Spy & 1 & 16 & 1 & 5 \\
\hline Corral & Beating & 4 & 16 and 20 & 2 & 4 \\
\hline Xcobiakal & Spy & 1 & 16 & 1 & 5 \\
\hline Corral & Beating & 3 & 16 and 20 & 1 & 5 \\
\hline
\end{tabular}


Biological aspects of hunted deer: the average weight of deer hunted in the study period was $42.66 \pm 19.13 \mathrm{~kg}$. The amount of total biomass harvested in the same period was $512 \mathrm{~kg}$, of which $455 \mathrm{~kg}$ was white-tailed deer O. virginianus (88.87\%) and $57 \mathrm{~kg}$ $(11.13 \%)$ of brocket deer M. american.

Table 2 shows the biometric features of 12 individuals harvested and one live fawn. The biometric values of the $M$. americana and $O$. virginianus specimens reported in this study (Table 2) are within the range reported by Segovia (2001) in Tzucacab and by Landewee (2009) in the Lagunas de Yalahau Yucatán State Reserve. It can be assumed that natural habitat conditions are appropriate to produce specimens with biometric values equal to that reported for deciduous and sub-deciduous forests of Yucatan.

It is important to report that animals were recorded that were "badly shot", ie animal that was not injured or hunted; (6/22), 13.6\% (3/22) was "wounded-badly shot", an animal that was injured by a bullet hit but not shot down and escaped, and 54.5\% (12/22) was "hunted" ie harvested, it means that it was shot down by bullet impact and used its meat.

Uses and exploitation: among the various uses associated with hunting deer according to the respondents, were: recognized as sources of food, commerce, ornaments, pets and handicrafts; however, it was corroborated as food with the majority of peasants / hunters during participatory observation, in some cases it was observed that the skin is used as leather to make tool covers, such as the machete, or to reinforce their shoes and cords); but in most cases only serves as food for hunting dogs; the skulls and teeth are sometimes sold to people coming from Playa del Carmen and Merida, to make handicrafts.

Meat is a natural resource of great importance for the human population that lives in the tropical regions of Latin America. Hunting of wildlife could negatively impact animal populations living there, according to Montes-Pérez et al. (2016) if hunting intensity were higher than the recruitment rate of local populations. In Yucatan, Mexico, there is little published information on the subject, which makes it difficult to pinpoint the magnitude of such wildlife utilization at the regional level. A survey of peasants $(n=731)$, showed that $58 \%$ carried out hunting for self-consumption, $15 \%$ to protect their crops and $24 \%$ for both purposes (Segovia et al., 2010). However, it is necessary to take into account the cases of meat offering or some other by-product such as skin for sale; if these cases were carried out with high frequency, at a given moment the hunt for self-consumption may become commercial, a situation that was not analyzed in this work. 
Table 2. Biological characteristics of white-tailed deer (Odocoileus virginianus) and brocket deer (Mazama americana) hunted (harvested) and not hunted in the three study sites.

\begin{tabular}{|c|c|c|c|c|c|c|}
\hline Locality & Deer & $\begin{array}{l}\text { Total } \\
\text { length }\end{array}$ & $\begin{array}{c}\text { Height } \\
\text { at the } \\
\text { withers }\end{array}$ & Sex & $\begin{array}{l}\text { Development } \\
\text { stage }\end{array}$ & Weight \\
\hline $\begin{array}{l}\text { Blanca } \\
\text { Flor }\end{array}$ & $\begin{array}{l}\text { White- } \\
\text { tailed }^{* *}\end{array}$ & & & Male & Young & \\
\hline $\begin{array}{c}\text { Blanca } \\
\text { Flor }\end{array}$ & $\begin{array}{l}\text { White- } \\
\text { tailed** }^{\star *}\end{array}$ & & & Male & Adult - & \\
\hline $\begin{array}{l}\text { Blanca } \\
\text { flor }\end{array}$ & Brocket & & & Female & Adult & \\
\hline Xcobiakal & $\begin{array}{l}\text { White- } \\
\text { tailed }^{\star \star}\end{array}$ & $100 \mathrm{~cm}$ & $59 \mathrm{~cm}$ & Female & Young adult & $24 \mathrm{~kg}$ \\
\hline Xcobiakal & Brocket & & & Male & & \\
\hline Xcobiakal & $\begin{array}{l}\text { White- } \\
\text { tailed** }^{*}\end{array}$ & $100 \mathrm{~cm}$ & $60 \mathrm{~cm}$ & Female & Young & $20 \mathrm{~kg}$ \\
\hline Xcobiakal & $\begin{array}{l}\text { White- } \\
\text { tailed }^{\star \star}\end{array}$ & & & Male & Adult & \\
\hline Xcobiakal & $\begin{array}{l}\text { White- } \\
\text { tailed }^{\star \star}\end{array}$ & $155 \mathrm{~cm}$ & $78 \mathrm{~cm}$ & Male & Adult & $60 \mathrm{~kg}$ \\
\hline Xcobiakal & Brocket & $105 \mathrm{~cm}$ & $69 \mathrm{~cm}$ & Male & Adulto & $25 \mathrm{~kg}$ \\
\hline Corral & $\begin{array}{l}\text { White- } \\
\text { tailed }^{* *}\end{array}$ & $112 \mathrm{~cm}$ & $63 \mathrm{~cm}$ & Female & Young adult & $26 \mathrm{~kg}$ \\
\hline Corral & $\begin{array}{l}\text { White- } \\
\text { tailed }^{* \star}\end{array}$ & $110 \mathrm{~cm}$ & $63 \mathrm{~cm}$ & Female & Young adult & 22 kg \\
\hline Corral & $\begin{array}{l}\text { White- } \\
\text { tailed }^{\star \star}\end{array}$ & & & Female & Adult & \\
\hline Corral & $\begin{array}{l}\text { White- } \\
\text { tailed }^{* *}\end{array}$ & & & Male & Adult & \\
\hline Corral & $\begin{array}{l}\text { White- } \\
\text { tailed }^{* *}\end{array}$ & & & Male & Young & \\
\hline Corral & $\begin{array}{l}\text { White- } \\
\text { tailed }^{* *}\end{array}$ & & & Female & Fawn & \\
\hline Corral & $\begin{array}{l}\text { White- } \\
\text { tailed }^{\star \star}\end{array}$ & $157 \mathrm{~cm}$ & $80 \mathrm{~cm}$ & Male & Adult & $62 \mathrm{~kg}$ \\
\hline Corral & Brocket & $116 \mathrm{~cm}$ & $72 \mathrm{~cm}$ & Male & Adult & 32 kg \\
\hline Corral & Brocket & & & Male & Adult & \\
\hline Corral & $\begin{array}{l}\text { White- } \\
\text { tailed** }^{*}\end{array}$ & $157 \mathrm{~cm}$ & $75 \mathrm{~cm}$ & Male & Adult & $56 \mathrm{~kg}$ \\
\hline Corral & $\begin{array}{l}\text { White- } \\
\text { tailed }^{* *}\end{array}$ & $155 \mathrm{~cm}$ & $80 \mathrm{~cm}$ & Male & Adult & $61 \mathrm{~kg}$ \\
\hline Corral & $\begin{array}{l}\text { White- } \\
\text { tailed }^{* *}\end{array}$ & $158 \mathrm{~cm}$ & $80 \mathrm{~cm}$ & Male & Adult & $69 \mathrm{~kg}$ \\
\hline Corral & $\begin{array}{l}\text { White- } \\
\text { tailed** }^{* *}\end{array}$ & $152 \mathrm{~cm}$ & $78 \mathrm{~cm}$ & Male & Adult & $55 \mathrm{~kg}$ \\
\hline
\end{tabular}

${ }^{*}$ Injured badly shot (wounded animal, but not hunting). ${ }^{* *}$ Badly shot neither (animal not injured nor hunting). ${ }^{* * *}$ Captured alive for being fawn. 
According to the participatory observation, only one hunter sold the deer meat, the main buyers being people from the urban area of the police stations near the hunter's home, paying for the product up to $\$ 80.00 \mathrm{~kg}$ (US \$ 8) when the legal price was $\$ 220$ per $\mathrm{kg}$ (Montes and Mukul, 2010).

The information generated shows the importance of hunting as an economic and social activity in Tzucacab, in this sense the results of this research yielded data of the economic activities to which the inhabitants of Tzucacab are dedicated, being the main agriculture and agriculture / hunting; in the case of Corral $100 \%$ to agriculture/hunting, in Xcobiakal $67 \%$ agriculture and $33 \%$ to agriculture / hunting and in Blanca Flor is $40 \%$ and $60 \%$ respectively. It is notorious that hunting is an activity practiced in the three communities on a daily basis as an alternative to cover their food and economic needs, particularly because the population of the municipality of Tzucacab is classified as highly marginalized (Hoyos, 2005).

Implications of deer hunting: the initial sample size that was assumed to execute this research, in terms of number of prey to be recorded during the time of the field study, was based on $10 \%$ ( $n=12$ animals) of reported by Segovia (2001), which indicates that in the municipality of Tzucacab, Yucatan, 120 deer are hunted annually, with an average of 9 deer per police station for a year.

The sampling of hunted animals recorded in our investigation included a participatory observation period during a week for four months in three police stations, recording 12 measured and heavy deer, three injured but not harvested (injured badly shot) and one live fawn; which gives an average of 4 deer harvested by police station. If one takes into account that the data were obtained in one week of each of the four months of sampling, then in one month of hunting the peasants / hunters would extract approximately 6 deer on average per month in each of the 13 existing police stations in Tzucacab, Yucatán. Assuming that the frequency of hunting was continuous throughout 12 months of the year, as reported by Segovia (2001) and Landewee (2009), then the estimated total would be the amount of 936 animals per year, or 2.5 deer per day Police station; this means that in the last 10 years the hunting pressure has increased. Thinking that this practice is carried out throughout the municipality of Tzucacab, and then it would represent the worst scenario in terms of hunting. If a conservative scenario is analyzed, in which half of the estimated previous one, that is to say 468 deer, will be hunted, which means that they hunted 3 deer by police station a month, in 13 police stations, during 12 months of the year. 
This calculation can not be proved by limitations in sampling effort, nor field verification of the harvest in animals or biomass; however, this analysis is congruent with the comments of the peasants / hunters themselves when asked their appreciation of the number of deer hunting now on what they hunted before; and many of them agree that they now hunt less, because they need to go further in order to achieve deer hunting; this explains the use of beat as a strategy to hunt, despite the fact that the meat yield for each participant is lower than the other hunting techniques, since with the beat and the use of trained dogs allow a greater probability of obtaining a piece at each hunting event.

On the other hand, it is important to indicate that in numerous published hunting reports, they only mention animals harvested in each hunting event, because it does not take into account those pieces that are not harvested, because they are lost because the shooter fails to knock down the prey with the shot and therefore the animal still injured escapes to the capture and probably dies in a place away from the hunting event; are animals called "badly injured", this situation aggravates the status of the population of deer, because it forces the hunter again to go out to hunt a prey again.

There is another important additional factor that increases the intensity of the hunt, it is the poaching, which was denounced in the interviews by the same peasants / hunters of the three communities; they are hunters from other cities who extract animals in each event, according to Segovia et al. (2010) has reported the presence of foreign groups of hunters who have better economic conditions and equipment to hunt deer, with the purpose of marketing mainly meat in different places in Yucatan. A recent report of this situation appears in Unotv.com (2017), where it is reported the capture of a man carrying $200 \mathrm{~kg}$ of deer meat in a trunk of car, without having the legal accreditation of provenance.

\section{CONCLUSION}

The hunting of deer (O. virginianus, $M$. americana) in three rural communities of the municipality of Tzucacab, Yucatan is a daily practice and frequent, in which they use the "beating" technique mainly; the objective of this hunt is to use of meat. The number of animals extracted from the habitat is greater than hunted, because there are injured deers but not shot down by bullet impact, which can not be hunted by the farmers/hunters.

\section{ACKNOWLEDGMENTS}

This work was financed by FOMIX-Government of the State of Yucatán; project number YUC-2006-C05-65725. 


\section{REFERENCES}

COBA LE. 2011. Análisis de la densidad poblacional, selección de hábitat y sexado remoto del venado cola banca (Odocoileus virginianus yucatanensis) en el municipio de Tzucacab, Yucatán, México (Tesis de Doctorado). Mérida, Yuc; México: Universidad Autónoma de Yucatán. 2011.

HOYOS PAA. 2005. Diagnóstico participativo. Consejo Municipal de Desarrollo Rural Sustentable de Tzucacab, Yucatán. PROFEMOR (Programa de Fortalecimiento a Empresas $\quad$ y Organización Rural). https://es.scribd.com/document/267500454/TZUCACAB-DIGANOSTICO-pdf

LANDEWEE D. 2009. Aprovechamiento de la Fauna Silvestre en el Parque Estatal Lagunas de Yalahau, Yucatán, México (Tesis de Maestría). Mérida, Yuc; México: Universidad Autónoma de Yucatán.

MARTÍNEZ-SALGADO C. 2012. El muestreo en investigación cualitativa. Principios básicos y algunas controversias. Ciéncia \& Saúde Coletiva. 17(3): 613-619. ISSN: 16784561. http://www.scielo.br/pdf/csc/v17n3/v17n3a06.pdf

MONTES-PEREZ R, Escobar-Bernal E, Albarracín-González Y, Adame-Erazo S, Camacho-Reyes J. 2016. Simulación de la dinámica poblacional de venados Odocoileus virginianus en la Orinoquia por modelación matemática. Abanico Veterinario. 6(1): 35-42. ISSN: 2448-6132. http://www.scielo.org.mx/pdf/av/v6n1/2448-6132-av-6-01-00035.pdf

MONTES-PEREZ R y Mukul YJM. 2010. Fauna silvestre como alternativa ganadera. En: Durán R y Méndez M, Biodiversidad y Desarrollo Humano en Yucatán. CICY, PPD-FMAN, CONABIO, SEDUMA. Mérida, Yucatán. Pág. 465-466. ISBN: 978-607-7823-05-6. http://www.seduma.yucatan.gob.mx/biodiversidad-

yucatan/05Parte4 Gestion Rec Nat/Capitulo9/05Fauna silvestre alternativa ganader a.pdf

MONTIEL S, Arias L. 2008. La cacería tradicional en el Mayab contemporáneo: una mirada desde la ecología humana. Avance y Perspectiva. 1(1): 21-27. ISSN: 0185-1411. http://www.mda.cinvestav.mx/proy faunaEN/caza yucatan2008.pdf

NARVÁEZ M. 2017. Cacería tradicional maya: subsistencia, tradición y comunidad. Agencia informativa Conacyt. Disponible en 
http://www.conacytprensa.mx/index.php/ciencia/humanidades/13925-caceria-tradicionalmaya-subsistencia-tradicion-y-comunidad. Acceso mayo de 2017.

NARANJO EJ, López-Acosta JC, Dirzo R. 2010. La cacería en México. Biodiversitas. 91:6-10. ISSN:

1870-1760.

\section{http://www.biodiversidad.gob.mx/Biodiversitas/Articulos/biodiv91art2.pdf}

ORELLANA LR, Espadas MC. Climas. 2010. En: Durán R y Méndez M, Biodiversidad y Desarrollo Humano en Yucatán. CICY, PPD-FMAN, CONABIO, SEDUMA. Mérida, Yucatán. Pág. 10-11. ISBN: 978-607-7823-05-6. http://www.cicy.mx/documentos/CICY/sitios/Biodiversidad/pdfs/Cap1/03\%20Climas.pdf

ROBLES DE BENITO R. 2010. La estrategia de conservación, manejo y aprovechamiento sustentable de la vida silvestre. En: Durán $R$ y Méndez M, Biodiversidad y Desarrollo Humano en Yucatán. CICY, PPD-FMAN, CONABIO, SEDUMA. Mérida, Yucatán. Pág. 427- 431. ISBN: 978-607-7823-05-6. http://www.cicy.mx/Documentos/CICY/Sitios/Biodiversidad/pdfs/Cap8/08\%20La\%20estr ategia\%20de\%20conservaci\%C3\%B3n.pdf

SEGOVIA CA. 2001. La cacería de subsistencia en Tzucacab, Yucatán, México. (Tesis de maestría). Mérida, Yuc; México. Universidad Autónoma de Yucatán.

SEGOVIA CA, Chablé SJ, Delfín GH, Sosa EJ, Hernández BS. 2010. Aprovechamiento de la fauna silvestre por comunidades mayas. En: Durán $R$ y Méndez $M$, Biodiversidad y Desarrollo Humano en Yucatán. CICY, PPD-FMAN, CONABIO, SEDUMA. Mérida, Yucatán. Pág. 385-387. ISBN: 978-607-7823-05-6. http://www.cicy.mx/Documentos/CICY/Sitios/Biodiversidad/pdfs/Cap7/20\%20Aprovecha miento\%20de\%20la\%20fauna.pdf

UNOTV.com. Hallan $200 \mathrm{~kg}$ de carne de venado en cajuela de auto en Yucatán. Disponible en: http://www.unotv.com/noticias/estados/yucatan/detalle/hallan-200-kg-departes-de-venado-en-cajuela-de-auto-en-yucatan-121038/. Acceso en mayo 2017. 